\title{
Masculine and metrosexual: Indonesian actor's clothing style on Instagram from the Foucauldian perspective
}

\author{
Teguh Dwi Putranto ${ }^{1^{*}}$, Rahma Sugihartati ${ }^{2}$, Santi Isnaini ${ }^{3}$, Suko Widodo ${ }^{4}$ \\ ${ }^{1}$ Faculty of Political and Social Science, Universitas Airlangga, Indonesia \\ ${ }^{3 \& 4}$ Department of Communication Science, Universitas Airlangga, Indonesia \\ ${ }^{2}$ Department of Information and Library Science, Universitas Airlangga, Indonesia \\ *Corresponding author \\ E-mail address: teguh.dwi.putranto-2019@fisip.unair.ac.id \\ DOI: https://doi.org/10.21107/sml.v3i2.7977
}

\begin{tabular}{|c|c|}
\hline Article Info & Abstract \\
\hline $\begin{array}{l}\text { Keywords: } \\
\text { Masculine } \\
\text { Metrosexual } \\
\text { Indonesian } \\
\text { Clothing style } \\
\text { Instagram }\end{array}$ & $\begin{array}{l}\text { This study seeks to explore the fashion styles of Indonesian actors on Instagram } \\
\text { from Foucault's perspective. Appearance is a demand that is not only aimed } \\
\text { at women but also for men. Appearance is an important part, especially for } \\
\text { men, so that also increases the metrosexual side. The enhancement of men's } \\
\text { appearance in clothing has increased metrosexuality. The metrosexual side } \\
\text { has been viewed by society as indicating the waning masculine side of a man. } \\
\text { Thus, some people believe that metrosexual men lose their identity entirely } \\
\text { because excessive attention to appearance is associated with women identity. } \\
\text { The method used in this study was the Krippendorff content analysis carried } \\
\text { out on Joe Taslim's Instagram account Instagram posts from October } 2019 \text { to } \\
\text { February 2020. Joe Taslim, known as an Indonesian action actor, is a figure } \\
\text { with a masculine appearance chosen in this study to represent a masculine } \\
\text { men figure but still looks metrosexual. The results of this study indicate that } \\
\text { Joe Taslim's Instagram is used as a medium in creating fantasies about the } \\
\text { men body metrosexual, which is run by the capitalist industry to create a } \\
\text { masculine impression. }\end{array}$ \\
\hline
\end{tabular}

\section{Citation suggestion:}

Putranto, T. D., Sugihartati, R., Isnaini, S., \& Widodo, S. (2020). Masculine and metrosexual: Indonesian actor's clothing style on Instagram from the Foucauldian perspective. Simulacra, 3(2), 209-222. https://doi.org/10.21107/ sml.v3i2.7977

Received 23 July 2020; Received in revised form 12 September 2020; Accepted 6 October 2020; Published online 25 November 2020. 


\section{Introduction}

Each country of the world has a specific concept of 'handsome'. For example, in Sweden, a handsome man is considered to have eyes that look sad; in Italy, fashionable; South Korea, cute impressions and smooth skin; India, muscular; England, clean and neat look; the United States, bearded; Brazil, curly hair; Turkey, trendy hairstyles, Greece, sharp look and dark skin; and Australia, perfect muscles (Amida, 2018). Meanwhile, based on previous research, representations of the physical appearance of Indonesian men are those with 'Indo' (mixed ethnic) faces. Meanwhile, if seen from the attitude, the ideal Indonesian men are those who are attentive, firm, ready to work, and are manly leaders (Yuliyanti et al., 2017). So, it can be concluded that 'handsome' is always related to what can be seen or in other words, physical appearance.

In mid-2019, TC Candler's official website "Independent Critics" revealed a list of the most attractive men and women in the world. Famous figures in this list of 100 most beautiful faces come from various parts of the world, including Bollywood stars like Shah Rukh Khan or Hollywood stars like Zac Efron or Robert Pattinson. From South Korea, Song Joong $\mathrm{Ki}$ and singers from BLACKPINK are also on this list. Not unlike Bollywood, Hollywood or Korean stars, several Indonesian artists were also nominated for the 100 most beautiful faces of TC Candler. They are Agnes Monica, Cinta Laura, Maudy Ayunda, Chelsea Islan, Al Ghazali and Joe Taslim (Kinapti, 2019).

Two of the six Indonesian artists are men, Al Ghazali and Joe Taslim. In fact, the age difference between the two is quite far. Al Ghazali is 22 years old while Joe Taslim is 38 years old. So, they are from different generations. Generational differences also affect a person in choosing a clothing style according to their age. Changes in clothing styles and lifestyles in the cultural structure of society make consumption of goods no longer based on the logic of necessity. (Umanailo et al., 2018). Based on the background of this problem, the researcher chose Joe Taslim because Joe Taslim is not only an advertisement star but also an action actor who is synonymous with a masculine side. However, on the other hand, Joe Taslim also continuously pays attention to his appearance, one of which is the choice of clothes.

Joe Taslim is the actor who played the role of Jaka in the film "The Raid." The film "The Raid" is an original Indonesian martial arts film. Not only in Indonesia, but he has also acted in foreign films around the world, including Fast \& Furious 6 (2016), Star Trek Beyond (2016), and Mortal Kombat. Not limited to movie screens, Joe Taslim has also been the cover model for several magazines, such as "Augustman," "Man's Folio," and

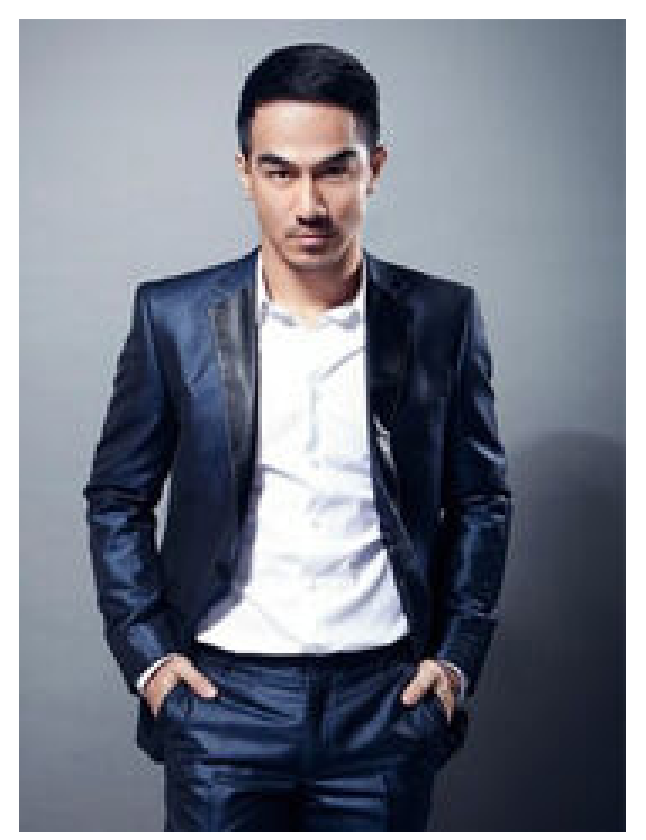

Figure 1. Portrait of Joe Taslim (Source: Fandom, 2018) 
many more. He is also the brand ambassador for several brands such as Telkomsel Hallo Hybrid, Nissan Juke, LG Mobile, Garnier People, Kratingdaeng, and the Molto Web series. These series of achievements and projects have helped Joe Taslim's career to grow and continue to shine (Pamugarwati, 2020). As an actor, Joe Taslim must be very concerned about appearance. Actors are frequently in the spotlight from the public, especially regarding their physical appearance.

Every culture has described gender presentation. For people, the typical men image is macho, muscular, rugged, beer or vodka drinking, rough, assertive, and aggressive. A man should enjoy sports, are rebellious, and adventurous. Nevertheless, a shift in desire and act of the people has been observed (Pan \& Jamnia, 2015). Appearances of men and women artists are getting increasingly demanded by society. Joe Taslim is known not only as a product brand ambassador, but also an action actor who is always identified with the term 'Macho.' Some of these previous studies have been described that macho men with rawness, trustworthy, effectiveness, and liking beer or vodka; they love sports, rebellious and adventurous. However, Joe Taslim has not fully embraced these images: his appearance is more in the tidy, clean, and metrosexual side.

Due to a variety of changes in lifestyle, education, xenophobia, and gay activism, the 'metrosexual' stereotype became more popular in the 21st century. Metrosexual is linked to lower masculinity levels, but not femininity, and homosexual preference (Mitchell \& Lodhia, 2017). The implicit masculine definition of oneself is not related to external expectation but is positively connected to several gender- related outcomes such as adherence to masculine norms, adoption of traditional concepts of masculinity, violent sexism and kind sexism (Mattos Feijó et al., 2018). Although the eroticisation of masculinity in the men body is growing, magazines still adopt the preferred masculinity brand as a traditional guy in formal attire (Khoo \& Karan, 2007). The media also plays a crucial role in introducing new representations of sexuality and gender, drawing attention due to the androgynous, macho, feminine, girly or very erotic characters they give their audience (Mercer \& Attwood, 2018). Thus, there is a shift in the meaning of masculinity to metrosexual, where masculinity is initially associated with physical abilities such as men physical strength. Today, however, masculinity affects how people feel about themselves. Therefore, men are often confused in determining their position between masculine and metrosexual. The difference is that metro sexuality is more associated with lower levels of masculinity, but not femininity. Meanwhile, masculinity does not arise from individual expectations externally but is positively related to several gender-related outcomes, such as adherence to masculine norms, adoption of traditional concepts of masculinity, violent sexism, and good sexism. The outcomes that emerge are then communicated through social media as an effort to show compliance with the norms against the concept of masculinity.

Social media has generated a new reality in people's daily lives in the current technical and internet transition era, especially (Aljuboori et al., 2020). Similar phenomena are happening in Indonesia. Indonesian social media users are composed of all age groups but are currently dominated by generations $\mathrm{Y}$ and $\mathrm{Z}$ of 18 to 34 years of age. In recent years, the use of social media 
has increased dramatically. In 2017 there were about 2.46 billion global online social networking (SNS) users. By the end of 2021, the number of social media users worldwide is expected to reach about 3.09 billion people (Müller et al., 2016). Various kinds of social media have been present in human life to facilitate all kinds of daily activities, one of which is Instagram.

Instagram as a popular social media makes peoplecompare the appearance of each other and triggers a sense of dissatisfaction with the body which can affect body image for each individual (Tiggemann et al., 2018). Compared to Facebook, Instagram is used more in branding strategies to convey brand associations and personality (Watkins \& Lee, 2017). Photo manipulation, as well as social media investment, has been linked to increased body dissatisfaction for both men and women. For both men and women, deception and attention to selfie can lead to body dissatisfaction (Lonergan et al., 2019). The application of the biopsychosocial paradigm to study human body dissatisfaction is beneficial and indicates the need to consider other variables in the perceptions of men body image contributors, such as peers and sports activity (BardoneCone et al., 2008).

Body dissatisfaction is related to the emergence of negative feelings towards the body, which is motivated by the difference between the perceived ideal body appearance and the actual body appearance (Grieve et al., 2007). Gender and condition are the primary factors of body dissatisfaction. Indeed, there is a substantial relationship between gender and conditions on changes in body dissatisfaction. Abstract contemplation predicts the highest increase in body dissatisfaction in women, whereas concrete contemplation predicts the highest increase in body dissatisfaction in men (Rivière et al., 2018). Appearance management is defined as individual actions, such as diet, exercise, and hairstyling, to maintain their overall appearance (Reilly \& Rudd, 2007).

The emergence of self-schemes and self-conformity mediates the influence of Instagram on body satisfaction. The impact of mediation also differentiates self-esteem on Instagram users. Those with lower self-esteem will feel a more significant negative effect from using Instagram on selfconfidence and body self-esteem (Ahadzadeh

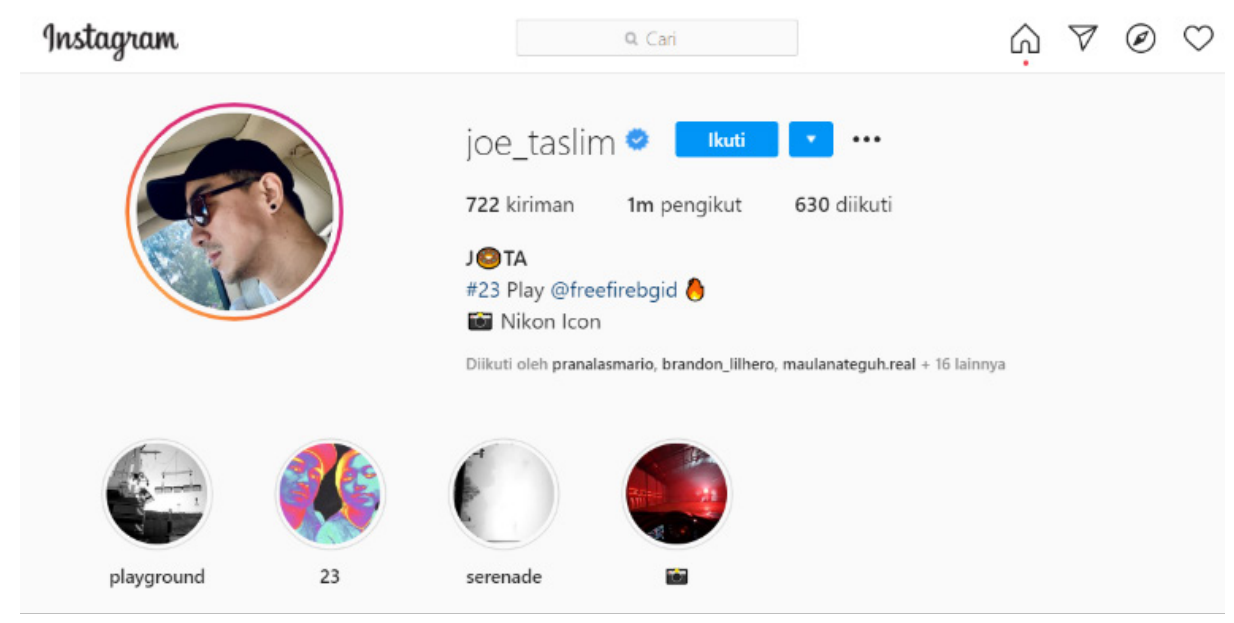

Figure 2. Joe Taslim's Instagram Profile

(Source: Instagram, 2020a) 
et al., 2017). Thus, Instagram is believed to be the right social media to analyse one's physical appearance from the positive and negative sides through self-posting.

Joe Taslim's metrosexual style of clothing is the focus of this research. Instagram, as one of the social media used by people in the digital era, is one of the tools to see the metrosexual appearance in Joe Taslim's clothes. This is because clothing buying behaviour is characterised as buying individual clothing that represents individual aesthetic preferences and tastes, presenting their uniqueness, and not necessarily following the latest trends. Public self-awareness refers to the level of individual care about their appearance and actions in a social context (Buss, 1985). Individual identities are defined in the roles they design for themselves, based on social position. Examining identity motives can help in understanding what influences a person to take on a particular role (McNeill, 2018). A person's decision in choosing clothes and accessories is a reflection of one's inner self, which can be either real-self or publicself (Gillani et al., 2016).

Moreover, Joe Taslim has been known as an action star with a macho image, but still maintains his appearance with a neat and clean appearance. The theory used in this research is Foucault's theory of power, which assumes that power is always closely related to knowledge: there is no power if there is no knowledge, and without power, there is no knowledge. Nevertheless, knowledge and power are not the same. Knowledge, on the one hand, has a powerful effect, and power requires knowledge (Foucault, 1993). Therefore, this study seeks to determine the clothing style of Indonesian actors on Instagram from Foucault's perspective.

\section{Method}

The method used in this research is content analysis, which is chosen to describe the aspects and characteristics of the post content. Text analysis is a systematic method that evaluates message content and message transmission or an analytical tool to monitor and analyse the available communication activity content of selected communicators (Kim, 2019). Content analysis is a scientific investigative tool for analysing information from communication sources such as television programs, newspaper columns, books, pictures, and the internet (Krippendorff, 2018).

The researcher used two coders to ensure objectivity in coding and data collection. The reliability test was used to check the validity of the data collected and to determine the accuracy of the data and was carried out by two coders. In addition, researchers also use Krippendorff Content Analysis to analyse Instagram posts. Researchers used content analysis to see the clothing styles of Indonesian actors on Instagram from October 2019 to February 2020 in Joe Taslim's Instagram posts, a total of 32 posts were studied. This study uses the Holsti formula to calculate the data obtained from the two coders (Samiei \& Mehrabi, 2019; Alam et al., 2020). The content analysis method was chosen because the researcher tried to see the humour of Instagram posts qualitatively, then the researcher tried to interpret the post content, read the symbols, interpret the symbolic interaction content that occurred in Joe Taslim's Instagram posts.

The steps taken by the researcher in this content analysis method are; first, the researcher looks at Joe Taslim's Instagram posts during the period from October 2019 
to February 2020. Second, the researcher chose Joe Taslim's Instagram posts with the consideration of posts that highlight his posting style. Third, after the posts are collected, the coder will sort the posts (sorted according to fashion style). Fourth, the collected data is then processed and analysed.

\section{$\mathrm{PAo}=2 \mathrm{~A} /(\mathrm{N} 1+\mathrm{N} 2)$}

Where PAo is the percentage of the agreement of the two coders, $\mathrm{A}$ is the number of decisions made by the two coders, N1 and $\mathrm{N} 2$ are the numbers of decisions made by the coders. There are several basic clothing styles for metrosexual men, including sweaters, button-down shirts, T-Shirts, Jeans, short coats (Sharma, n.d.).

\section{Results and Discussion}

Researchers collected 32 posts from Joe Taslim's Instagram during October 2019 February 2020. Before analysing the data, the researcher used the Holsti formula to check the reliability of the data. Several types of clothing are used as indicators of metrosexuality, including sweaters, buttondown shirts, T-shirts, jeans, and short coats.

$$
\begin{aligned}
\text { PAo } & =2 \mathrm{~A} /(\mathrm{N} 1+\mathrm{N} 2) \\
& =2(24) / 32+32 \\
& =48 / 64 \\
& =0.75(75 \%)
\end{aligned}
$$

Data is said to be reliable if it can reach a tolerance value with a minimum value of 70 per cent or above 0.7 (Holsti, 1969). From the results of data calculations that have been obtained using the Coder Holsti reliability formula, the reliability element is at 0.75 or 75 per cent. Therefore, the data obtained is declared reliable because it exceeds the minimum limit.

\section{The power of Instagram and public figures}

Researchers use Foucault's power theory with the assumption that power is always closely related to knowledge: there will be no power if there is no knowledge, and without power, there will be no knowledge. On the one hand, knowledge has a strong influence, and power requires knowledge.

Instagram, which is one of the most popular social media platforms in the world, currently has hundreds of millions of active users. Indonesia is a country with the most active Instagram users, so of course, Instagram occupies a unique position compared to other social media. Moreover, various interesting features owned by Instagram make users spoiled so that many are addicted to it (Wardani, 2019). Seeing the habits of Instagram users who have been very comfortable with its features, many do not realise they have become targets for many parties, such as the capitalist industry. Therefore, Instagram can be perceived as a place that is mutually needy and profitable.

Various kinds of activities have moved to the digital realm, one of which is consumption. Not only information consumption, consumption of goods and services are also offered on Instagram. Instagram has changed many aspects of human life. The offers for pseudo-reality and hyperreality on Instagram have flowed along with the goals of the capitalist industry. The reality that is built through Instagram through unilateral consumption activities has benefited capitalist industry players. This advantage does not stop at conventional supply in achieving capitalist goals. The 
Table 1. Post Analysis by Two Coders

\begin{tabular}{|c|c|c|c|c|c|c|c|c|c|c|}
\hline \multirow{2}{*}{$\begin{array}{l}\text { Date } \\
\text { Oct }\end{array}$} & \multicolumn{5}{|l|}{ Coder 1} & \multicolumn{5}{|l|}{ Coder 2} \\
\hline & Sweaters & $\begin{array}{l}\text { Button-down } \\
\text { shirts }\end{array}$ & T-Shirt & Jeans & Short Coat & Sweaters & $\begin{array}{l}\text { Button-down } \\
\text { shirts }\end{array}$ & T-Shirt & Jeans & $\begin{array}{l}\text { Short } \\
\text { Coat }\end{array}$ \\
\hline 7 & & & & & & & & & & \\
\hline \multicolumn{11}{|l|}{9} \\
\hline \multicolumn{11}{|l|}{18} \\
\hline \multicolumn{11}{|l|}{20} \\
\hline \multirow{2}{*}{\multicolumn{11}{|c|}{$\frac{23}{27}$}} \\
\hline \multirow{2}{*}{\multicolumn{11}{|c|}{$\frac{27}{28}$}} \\
\hline & & & & & & & & & & \\
\hline \multicolumn{11}{|l|}{ Nov } \\
\hline \multicolumn{11}{|l|}{8} \\
\hline \multicolumn{11}{|l|}{28} \\
\hline \multicolumn{11}{|l|}{ Dec } \\
\hline \multirow{2}{*}{\multicolumn{11}{|c|}{$\frac{15}{26}$}} \\
\hline \multirow{2}{*}{\multicolumn{5}{|c|}{26}} & & & & & & \\
\hline & & & & & & & & & & \\
\hline \multicolumn{11}{|l|}{14} \\
\hline \multicolumn{11}{|l|}{15} \\
\hline \multicolumn{11}{|l|}{16} \\
\hline \multicolumn{11}{|l|}{$\frac{18}{19}$} \\
\hline \multirow{2}{*}{\multicolumn{11}{|c|}{$\frac{19}{21}$}} \\
\hline & & & & & & & & & & \\
\hline \multicolumn{11}{|l|}{23} \\
\hline \multicolumn{11}{|l|}{25} \\
\hline \multirow{2}{*}{\multicolumn{11}{|c|}{$\frac{\mathrm{Feb}}{3}$}} \\
\hline \multirow{2}{*}{\multicolumn{11}{|c|}{$\frac{3}{4}$}} \\
\hline & & & & & & & & & & \\
\hline \multicolumn{11}{|l|}{5} \\
\hline 6 & & & & & & & & & & \\
\hline 10 & & & & & & & & & & \\
\hline 12 & & & & & & & & & & \\
\hline 14 & & & & & & & & & & \\
\hline 20 & & & & & & & & & & \\
\hline 24 & & & & & & & & & & \\
\hline 26 & & & & & & & & & & \\
\hline 26 & & & & & & & & & & \\
\hline 27 & & & & & & & & & & \\
\hline 27 & & & & & & & & & & \\
\hline & 5 & & 10 & 5 & 6 & 8 & 7 & 6 & 1 & 10 \\
\hline & 32 & & & & & 32 & & & & \\
\hline
\end{tabular}

conventional offer in consumption activities has shifted to the strategy of creating reality and discourse, especially in the men's body.

Customer needs are increasing along with the offer of advertisements in various media. Advertising defines consumer wants and expectations as needs that must be met and of course, fulfilled by consuming advertised products (Rahayu \& Afrianto, 2017). Consumption activities are indeed more identified with the habits of women rather than men and more identified with the habits of women than men. However, nowadays, consumption activities are also carried out by men. This certainly opens up opportunities to get new men customers.

Instagram can be a container in bridging the goals of capitalist goals. In addition, Instagram almost blurs the distance from anyone, a distinct advantage for Instagram users. The distance referred to, for example, between ordinary people and community leaders such as artists or actors. Instagram also eliminates distance and provides 
intimacy in the digital world by satisfying the desires of the general public for an idolised figure. The capitalist industry has not missed Instagram's effect on distance.

The fame of public figures has become a magnet for fans which is used as a strategy in launching a capitalist industry to build a consumerist culture on Instagram through the body. The distance between fans and idols that Instagram has blurred is used as an effort to build a false reality, especially about body discipline. The capitalist industry uses the idol figure coveted by fans of public figures (artists or actors) presented by Instagram in achieving their objectives. The capitalist industry presents an ideal body figure through public figures (artists or actors) so that people, especially those who are interested, can be constructed by community figures in order to realise the reality simulation desired by the industry. Because the body is not only seen as a body but has been seen as an instrument of discipline. It is also seen as an entity that can still be tampered. This concept eventually becomes an opening for the capitalist industry to take advantage of the concept of a body that can still be tampered with as to what the capitalist industry wants to shape (Foucault, 2000). Whatever is worn by the body, especially clothes is not only an object to protect the body. Clothing has become a means of demonstration of identity. The combination of public figures and Instagram fame makes what public figures do or wear a fatal combination. The existence of public figures that become magnets (attraction) makes anyone who sees them, especially their fans, always want to try to imitate, especially in clothes.

Based on Joe Taslim's Instagram post, it can be seen that T-Shirts are a fashion style that accentuates the masculine side more than other clothing styles. T-Shirts are seen as a clothing style that tends to be relaxed but can still show the wearer neatness. Through Joe Taslim's Instagram post, the T-Shirt has become a style of clothing for metrosexual men but still masculine. Instagram is a medium for building knowledge in the minds of its users; in this case, Joe Taslim's Instagram enthusiasts or followers. The power of Instagram is utilised as a process of creating body discipline, which is an extension of knowledge to Joe Taslim's Instagram enthusiasts or followers to create a simulation of Joe Taslim's clothing style.

\section{Men's body as a form of identity}

The choice of the clothes' colour, of course, has also gone through several considerations before finally being used. The reason is, the combination of suitable clothes will bring a sense of comfort, and a sense of comfort when wearing the clothes of choice will bring out the wearer's confidence. In Figures 3 and 4 , we can see that the post features Joe Taslim wearing a black shirt. People who like the colour brown tend to be someone who does not like complexity. Besides that, the brown colour is also simple. He appears to have reasonable emotional control and tends to be stable, humble, friendly, and easy to get along with (Sukma, 2018).

Based on data collected from Instagram Joe Taslim, we can make some inference related to the choice in clothing. Metrosexual men make their desire in appearance an obligation that must be fulfilled to show their existence in the real world and cyberspace. They pay more attention to their bodies, one of which is through the clothes they wear. Each chosen colour also describes the wearer's personality. This can be a sign that is created so that anyone who sees it can 


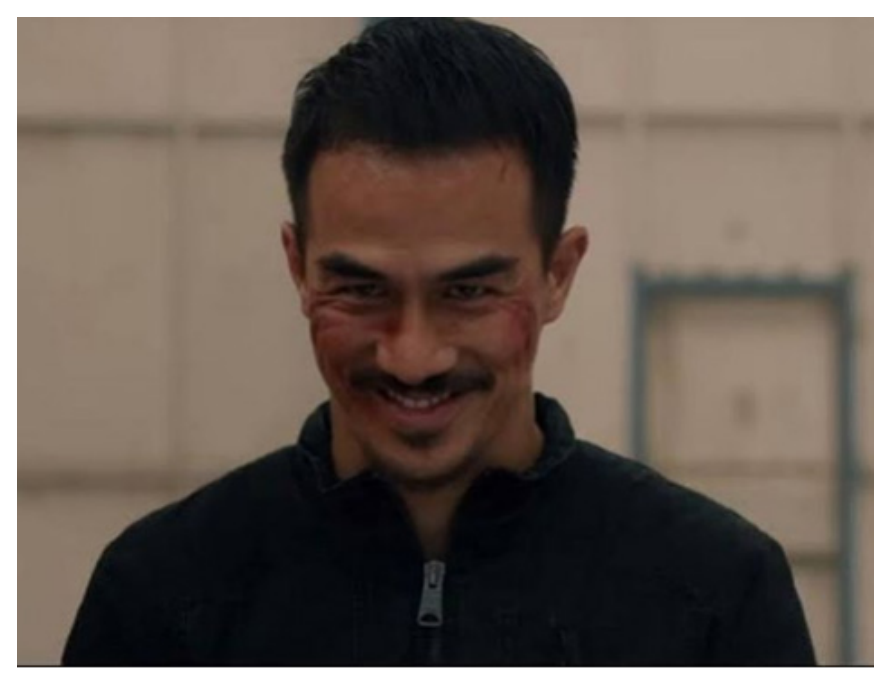

Figure 3. Post on 27 February 2020

(Source: Instagram, 2019)

give more meaning. For example, Figure 3, like most of Joe Taslim's posts, is dominated by clothing choices with dark colours. The clothing choices of black, brown, and several other dark colours in Joe Taslim's post are shown not only in Figure 3 but also in Figure 4.
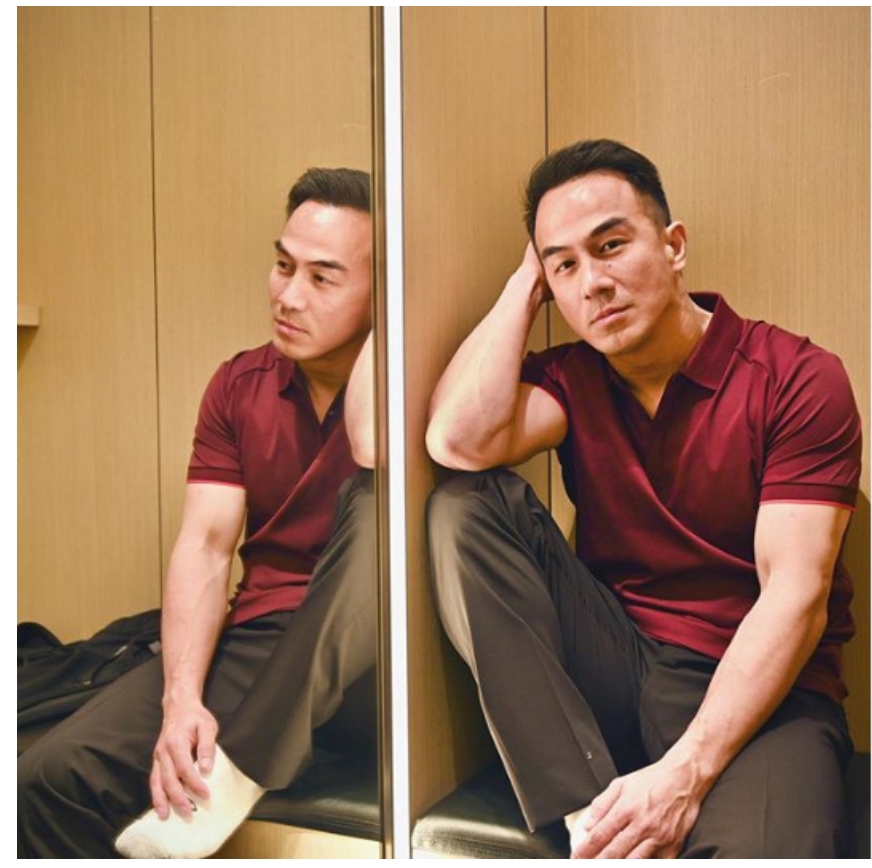

Figure 4. Post on 27 February 2020 (Source: Instagram, 2020c)
Thus, from these posts, from the way he is clothing, Joe Taslim prefers clothes that are dominated by dark colours to portray a bold character. From here, there appears to be a change in the depiction of hegemonic masculinity from a macho image to a metrosexual image conditioned by the existence of capitalism and consumerism. However, the transformation that occurs is only in physical appearance, not at its essence (Suprapto, 2018).

Indeed, choosing colours and patterns on clothes can influence one's perception. Furthermore, clothes can show a person's social class in society. This is related to the excessive consumption of clothing, especially for certain brands whose prices are above the average. Of course, such consumption cannot be carried out by those who do not have enough money to buy clothes with certain brands and at high prices. Metrosexual men who are identified with metropolis life are increasingly required to fulfil their needs in supporting their appearance, especially in buying branded clothes as a form of consumption activity. This effort also contributes to building the self-image of men who want to look attractive, but still, look masculine as a men identity.

Moreover, as a macho acting star, Joe Taslim's daily appearance is very much noticed. Self-appearance is built through the body, so that knowledge of a men's body which is covered in certain clothes is used so that every man always pays attention to his appearance. Clothing is not just an inanimate object; clothing has become a tool for individuals to show their identity. So that clothes are used as strength in building knowledge about the identity of each wearer. 


\section{The exploitation of metrosexual men bodies}

Brand selection is no less critical for metrosexuals in showing their identity. Because the selection of brands sends a message to anyone who sees it, on the other hand, those who see it will interpret the non-verbal message they get. In Joe Taslim's Instagram post on 26 February 2020, Joe Taslim is seen standing in front of the words "HUGO BOSS." The researcher concludes that "HUGOBOSS" is a German-based luxury fashion brand that relates to the lifestyle of the bourgeoisie. The body becomes an entity whose concept can be changed according to the wishes of the capitalist industry and to carry out the practice of disciplining the body by a particular brand. The body is made to be the object of exploitation in carrying out capitalist goals to encourage people to carry out consumption activities by establishing brand equity fantasy.

Brand equity has been accepted as an essential construct, as evidenced by the development of models and arguments, as well as various definitions that reflect the commercial intentions of brands (Naidoo \& Abratt, 2018). Brand equity is also defined as the preferences and differential responses to various marketing efforts obtained from products identified by the brand. Brand equity can also be measured through consumer perceptions or sales (Datta et al., 2017). Based on these IG posts, a brand, especially a clothing brand, can be a tool to show people's fashion sense. Appearances are the most highlighted by metrosexuals and are used as a tool to show their lifestyle. Joe Taslim, as one of the Indonesian actors who are well known not only nationally but also internationally, certainly has a massive influence in attracting the attention of his fans. This popularity is undoubtedly used by brands such as HUGO BOSS to create a metrosexual lifestyle in the fashion sector. Moreover, if the brand used is a well-known brand, the effort in creating a definition of a metrosexual lifestyle and way of clothing will be easier.

The figure of Joe Taslim, an action actor with a manly appearance, is the ideal men figure. Thus, Joe Taslim's taste in appearance becomes a fashion model for metrosexual men without leaving a macho impression, different from what is usually more related to skincare. Judging from the brand, HUGO BOSS itself is a well-known brand from Germany. So, through this post, the German fashion style is influential in presenting the impression of metrosexuality.

The body, in both men and women, has undergone a significant disciplinary process. The masculine impression on men has shifted along with the times that also present men representations of the modern era. As an action actor who is known for his macho appearance, of course, Joe Taslim is a magnet for men who want to look attractive but still

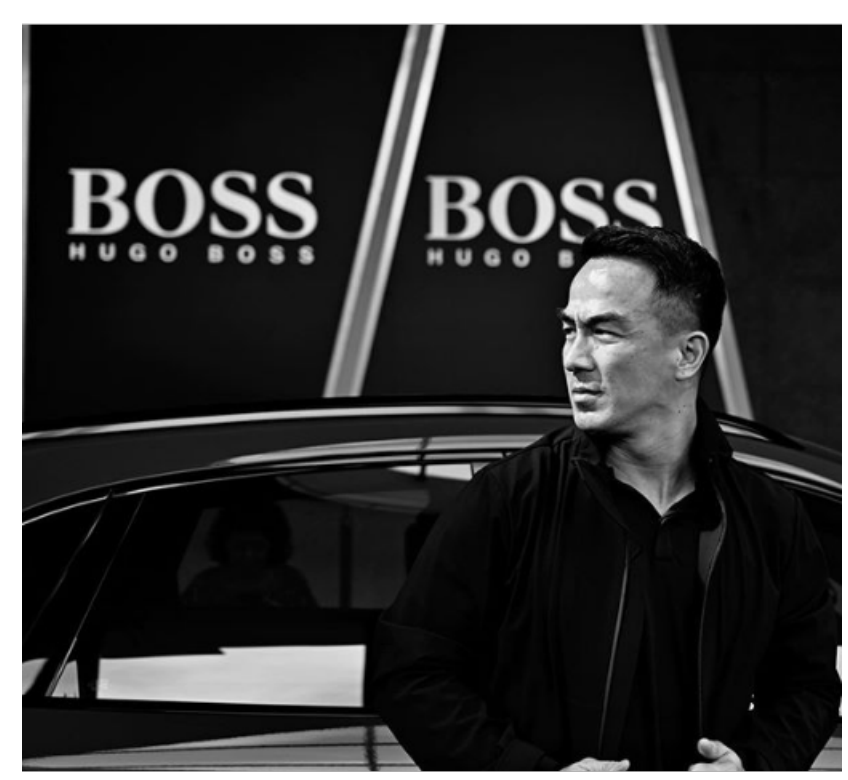

Figure 5. Post on 26 February 2020 (Source: (Instagram, 2020b) 
appear masculine. This, of course, can be an excellent opportunity for specific brands, especially clothing brands, in running the capitalist industry by utilising the men body as a medium in creating the latest ideal body and appearance. Increased public consumption, especially in urban areas, has undoubtedly opened opportunities for brands to carry out capitalism through the body. From Foucault's perspective, the body of a metrosexual man becomes the object of exploitation by a particular Brand as a capitalist industry. The capitalist industry further exploits this condition in mastering the imagination and fantasies of metrosexual men. These imaginations and fantasies have finally led to the urge of the metrosexual man who is known to be very concerned about his appearance, one of which is in fashion through body discipline through branded clothes. Thus, the taste of metrosexual men in choosing clothes is also driven by the consideration of certain brands.

\section{Conclusion}

Viewed from Foucault's perspective on power theory, Joe Taslim's Instagram post is used as a power in building men fantasy and knowledge, especially metrosexual men, but does not reduce masculinity. So that from Foucault's perspective, the power in Joe Taslim's Instagram post is played by the capitalist industry as an extension of the capitalist efforts of the men fashion industry and the culture of metrosexual men consumption on Instagram. This research is limited to disciplining the men body by Indonesian actors on Instagram in fashion so that the suggestions for this research in the future can review related topics from other social media.

\section{Declaration of Ownership}

This article is our original work.

\section{Conflict of Interest}

There is no conflict of interest to declare in this article.

\section{Ethical Clearance}

This study was approved by the institution.

\section{References}

Ahadzadeh, A., Sharif, S., \& Ong, F. (2017). Self-schema and self-discrepancy mediate the influence of Instagram usage on body image satisfaction among youth. Computers in Human Behavior, 68, 8-16. https://doi.org/https://doi.org/10.1016/j. chb.2016.11.011

Alam, W., Marijan, K., Aminah, S., \& Putranto, T. (2020). Drug eradication in indonesian millennials through school visits. Journal of Drug and Alcohol Research, 9(1), 1-6. https://doi.org/10.4303/jdar/236089

Aljuboori, A., Fashakh, A., \& Bayat, O. (2020). The impacts of social media on University students in Iraq. Egyptian Informatics Journal, 21(3), 139-144. https://doi.org/ https://doi.org/10.1016/j.eij.2019.12.003

Amida, A. (2018). Definisi ketampanan di 10 negara ini menunjukkan kalau standar ganteng itu berbeda-beda. https:// www.rimma.co/62790/inspiration/ definisi-ketampanan-di-10-negara-inimenunjukkan-kalau-standar-gantengitu-berbeda-beda/

Bardone-Cone, A., Cass, K., \& Ford, J. (2008). Examining body dissatisfaction in young men within abiopsychosocial framework. Body Image, 5(2), 183-194. https://doi. org/10.1016/j.bodyim.2007.12.004 
Buss, D. (1985). Human mate selection: Opposites are sometimes said to attract, but in fact we are likely to marry someone who is similar to us in almost every variable. American Scientist, 73(1), 47-51.

Datta, H., Ailawadi, K., \& Van Heerde, H. (2017). How well does consumerbased brand equity align with salesbased brand equity and marketing-mix response? Journal of Marketing, 81(3), 1-20. https://doi.org/10.1509/jm.15.0340

Fandom. (2018). Joe Taslim. https:// mortalkombat.fandom.com/wiki/Joe_ Taslim

Foucault, M. (2000). Sejarah seksualitas: Seks dan kekuasaan. PT. Gramedia Pustaka Utama.

Gillani, B., Haider, S., \& Jan, F. (2016). The relationship of clothing with personal identity of different clothing style personalities among working women. Journal of Management Info, 3(1), 1-4. https://doi.org/10.31580/jmi.v9i1.43

Grieve, P., Stark, R., Isler, J., Housman, S., Fifer, W., \& Myers, M. (2007). Electrocortical functional connectivity in infancy: Response to body tilt. Pediatric Neurology, 37(2), 91-98. https://doi. org/10.1016/j.pediatrneurol.2007.04.004

Holsti, O. (1969). Content analysis for the social sciences and humanities. Reading. MA: Addison-Wesley (Content Analysis).

Instagram. (2019). Joe Taslim's Instagram Post on October, 18 2019. https://www. instagram.com/p/B3vySoMJNjS/

Instagram. (2020a). Display of joe taslim's instagram profile. https://www.instagram. com/joe_taslim/?hl=id

Instagram. (2020b). Joe Taslim's Instagram Post on February 26, 2020. https://www. instagram.com/p/B9BnvVbpWwI/

Instagram. (2020c). Joe Taslim's Instagram Post on February 27, 2020. https://www. instagram.com/p/B9DGf3MpODX/
Khoo, M., \& Karan, K. (2007). Macho or metrosexual: The branding of masculinity in FHM magazine in Singapore. Intercultural Communication Studies, 16(1), 34.

Kim, H. (2019). Globalization and regulatory change: The interplay of laws and technologies in E-commerce in Southeast Asia. Computer Law and Security Review, 35(5), 1-20. https://doi.org/10.1016/j. clsr.2019.03.009

Kinapti, T. (2019). 6 seleb indonesia ini masuk nominasi orang tercantik dan tertampan di dunia 2019. https://hot.liputan6.com/ $\mathrm{read} / 4002734 / 6$-seleb-ind onesia-inimasuk-nominasi-orang-tercantik-dantertampan-di-dunia-2019

Krippendorff, K. (2018). Content analysis: An introduction to its methodology. Sage publications.

Lonergan, A., Bussey, K., Mond, J., Brown, O., Giffiths, S., Muray, S., \& Mitchison, D. (2019). Me, my selfie, and I: The relationship between editing and posting selfies and body dissatisfaction in men and women. Body Image, 28(3), 39-43. https://doi.org/10.1016/j. bodyim.2018.12.001

Mattos Feijó, L., Tarman, G., Fontaine, C., Harrison, R., Johnstone, T., \& Salomons, T. (2018). Sex-specific effects of gender identification on pain study recruitment. Journal of Pain, 19(2), 178-185. https://doi. org/10.1016/j.jpain.2017.09.009

McNeill, L. (2018). Fashion and women's self-concept: a typology for selffashioning using clothing. Journal of Fashion Marketing and Management, 22(1), 82-98. https://doi.org/10.1108/JFMM-092016-0077

Mercer, J., \& Attwood, F. (2018). The metrosexual: Figures of masculinity. Routledge.

Mitchell, V., \& Lodhia, A. (2017). Understanding the metrosexual and spornosexual as a segment for 
retailers. International Journal of Retail and Distribution Management, 45(4), 349-365. https://doi.org/10.1108/ IJRDM-05-2016-0080

Müller, K., Dreier, M., Beutel, M., Duven, E., Giralt, S., \& Wölfling, K. (2016). A hidden type of internet addiction? Intense and addictive use of social networking sites in adolescents. Computers in Human Behavior, 55(February), 172-177. https:// doi.org/10.1016/j.chb.2015.09.007

Naidoo, C., \& Abratt, R. (2018). Brands that do good: Insight into social brand equity. Journal of Brand Management, 25, 5-13. https://doi.org/10.1057/s41262-017-00722

Pamugarwati, A. (2020). Profil Joe Taslim, aktor laga yang mendunia. https://entertainment.kompas. $\mathrm{com} / \mathrm{read} / 2020 / 01 / 28 / 194448310 /$ profil-joe-taslim-aktor-laga-yangmendunia\#: : text=Priakelahiran Palembang\%2C 23 Juni, memainkan beberapa film laga lainnya.\&text=Tidak hanya di tanah air,(2016) dan Mortal Kombat.

Pan, H., \& Jamnia, M. (2015). Concept and phenomenon:A metrosexual perspective. Global Journal of Arts Humanities and Social Sciences, 3(5), 22-34.

Rahayu, N., \& Afrianto, D. (2017). Representasi citra laki-laki dalam iklan Gatsby styling pomade kajian semiotika Roland Barthes. Capture: Jurnal Seni Media Rekam, 9(1), 93-107.

Reilly, A., \& Rudd, N. (2007). Stress and dress: Investigating the relationship between social anxiety and appearance management among gay and straight men. Journal of Homosexuality, 52(34), 151-166. https://doi.org/10.1300/ J082v52n03_07

Rivière, J., Rousseau, A., \& Douilliez, C. (2018). Effects of induced rumination on body dissatisfaction: Is there any difference between men and women? Journal of Behavior Therapy and Experimental Psychiatry, 61, 1-6. https:// doi.org/10.1016/j.jbtep.2018.05.005

Samiei, D., \& Mehrabi, Z. (2019). Content analysis of the first chapter of the twelfth grade chemistry book based on the William Romey's method and determining its importance with the Shannon entropy method. Research in Chemistry Education 1(3), 53-72.

Sharma, T. (n.d.). Styles of the metrosexual male. https://mens-fashion.lovetoknow. com/Styles_of_the_Metrosexual_ Male\#: :text=The metrosexual subscribes to the, be worn in solid colors

Sukma, D. (2018). 7 karakter positif ini cuma dimiliki penyuka warna cokelat. https:// www.idntimes.com/life/inspiration/ sukma-satiti/7-karakter-positifpenyuka-warna-cokelat-c1c2/7

Suprapto, D. (2018). Representasi maskulinitas hegemonik dalam iklan. Jurnal Penelitian dan Pengembangan Sains dan Humaniora, 2(1), 1-11. https://doi. org/10.23887/jppsh.v2i1.14004

Tiggemann, M., Hayden, S., Brown, Z., \& Veldhuis, J. (2018). The effect of Instagram "likes" on women's social comparison and body dissatisfaction. Body Image, 26(9), 90-97. https://doi.org/10.1016/j. bodyim.2018.07.002

Umanailo, M., Nawawi, M., \& Pulhehe, S. (2018). Konsumsi menuju konstruksi masyarakat konsumtif. Simulacra, 1(2), 203-211. https://doi.org/10.21107/sml. v1i2.4995

van de Grift, T., Cohen-Kettenis, P., Steensma, T., De Cuypere, G., Richter-Appelt, H., Haraldsen, I., Dikmans, R., Cerwenka, S., \& Kreukels, B. (2016). Body satisfaction and physical appearance in gender dysphoria. Archives of Sexual Behavior, 45(3), 575-585. https://doi.org/10.1007/ s10508-015-0614-1

Wardani, A. (2019). Jumlah pengguna Instagram dan Facebook Indonesia terbesar 
ke-4 di dunia. https://www.liputan6.com/ tekno/read/3998624/jumlah-penggunainstagram-dan-facebook-indonesiaterbesar-ke-4-di-dunia

Watkins, B., \& Lee, J. (2017). Communicating brand identity on social media: A case study of the use of Instagram and Twitter for collegiate athletic branding. International Journal of Sport Communication, 9(4), 476-498. https://doi. org/10.1123/ijsc.2016-0073
Yuliyanti, F., Bajari, A., \& Mulyana, S. (2017). Representasi maskulinitas dalam iklan televisi Pond's men \#Lelakimasakini (analisis semiotika Roland Barthes terhadap representasi maskulinitas). Jurnal Komunikasi, 9(1), 16-30. https://doi. org/10.24912/jk.v9i1.180 